\title{
Private International Law: An Appropriate Means to Regulate Transnational Employment in the European Union?
}

\author{
Aukje A.H. van Hoek*
}

\begin{abstract}
The regulation of transnational employment in the European Union operates at the crossroads between private international law and internal market rules. The private international law rules are currently laid down in the Rome I Regulation. This regulation is complemented by the Posted Workers Directive, a directive based on the competences of the EU in the field of free movement of services. The current contribution first describes the rules which determine the law applicable to the employment contract under Article 8 Rome I Regulation and the way these rules are interpreted by the CJEU before critically analysing these rules and the reasoning that seems to lie behind the court's interpretation (section 2). The law applying to the contract is, however, only of limited relevance for the protection of posted workers. This is due inter alia to the mandatory application of certain rules of the country to which the workers are posted, even if a different law governs their contract. This application of host state law is based on Article 9 Rome I Regulation in conjunction with the Posted Workers Directive. Section 3 describes the content of these rules and the - to some extent still undecided - interaction between the Rome I Regulation and the PWD. The conclusion will be that there is an uneasy match between the interests informing private international law and the interests of the internal market, which is not likely to be resolved in the near future.
\end{abstract}

Keywords: private international law, applicable law, overriding mandatory provisions, transnational employment relations, posting of workers

\section{Introduction}

The regulation of labour migration is one of the key aspects of sovereignty. Though not uncontested from a philosophical point of view, modern states tend to consider themselves exclusively competent to regulate incoming labour migration. ${ }^{1}$ To a lesser extent, states also may feel the need to regulate outgoing labour

\footnotetext{
Aukje van Hoek is Professor at the University of Amsterdam.

1. On this issue: C. Nwachukwu Okeke and J.A.R. Nafziger, 'United States Migration Law: Essentials for Comparison', 54 AJCL 531-52, at 534 (2006); J.F. Hollifield, 'The Emerging Migration State', 38 International Migration Review 885-912, at 887 and 890-91 (2004).
}

migration. ${ }^{2}$ Such regulation may serve different goals: all at the same time and to a different extent, depending on the socio-economic circumstances. ${ }^{3}$ Generally, states will want to control the influx and outflow of workers in order to prevent disbalances on the labour market and social unrest. This concern may relate purely to the numbers of outgoing or incoming workers, e.g. when emigration countries try to prevent a brain drain. But also the conditions under which the internationally mobile workforce is employed, are part of state regulation in some way.

The regulation of employment conditions in migration law may impact on the type of workers eligible for migration, e.g. restrict the influx to workers earning above a certain threshold wage, but this type of regulation is also meant to ensure a certain measure of protection to the migrant workers themselves on the one hand and prevent differences in employment conditions between local workers and migrants disrupting the local labour market on the other. However, when migration law starts regulating employment conditions, it enters a field also occupied by the rules of private international law.

In the EU, labour migration is part of the internal market. Both permanent migration and temporary posting of workers in the context of the cross-border provision of services are protected freedoms under the Treaty on the Functioning of the EU. This means inter alia that administrative controls on migration are abolished, which has also removed the protective function of migration law. The task to protect mobile workers as well as local labour markets against social dumping is delegated almost exclusively to the rules on applicable

2. E.g. Act concerning placing and protection for Indonesian Workers in Foreign Countries, cited in: I. Susanti, The Conflict Rules on the Protection of the Rights of Migrant Workers - A Proposition for Indonesia and ASEAN (2008), at 202. See for examples of similar regulation in Pakistan: <http://beoe.gov.pk/Ordinance.asp>, India: <http://moia.gov. in/services.aspx?id1=75andid=m1 andidp=75andmainid=73>; <http:// moia.gov.in/pdf/emigration_clearance.pdf $>$ and the Philippines: <www. poea.gov.ph/s.

3. For a succinct description of the goals of the Singapore regulation of incoming labour migration see <www.mom.govsg/Documents/foreignmanpower/EFMA/EFMA-Executive-summary.pdf $>$. 
law. ${ }^{4}$ In this chapter I will discuss these rules, in particular Articles 8 and 9 of the Rome I Regulation, and the interpretation given to these articles in the case law of the Court of Justice of the EU (CJEU). The private international law rules in turn will be put into the context of the internal market, in particular the rules on the free provision of services and the specification thereof in the Posted Workers Directive (PWD). ${ }^{5}$ Due to this particular perspective, the discussion will focus on the law of the place of work: to what extent is private international law instrumental in guaranteeing a level playing field. The concluding paragraph will summarise the main points of tension both within and between the two systems.

\section{The Law Applicable to Individual Employment Contracts under the Rome I Regulation}

\subsection{Articles 3 and 8 of the Rome I Regulation: Content of the Provisions}

The Rome I Regulation applies in all Member States of the EU with the exception of Denmark. ${ }^{6}$ Courts of the Member States will apply the regulation to all international employment contracts concluded as from 17 December 2009. ${ }^{7}$ According to Article 2 the regulation has universal application, which means it will apply even when the conflict-of-law rules contained therein declare the law of a non-Member State to be applicable to the contract.

The Rome I Regulation is based on party autonomy. According to Article 3 the parties to a contract may designate the law applicable to the contract themselves. This chosen law will be the law governing the contract - the lex causae. The regulation does not contain any requirement as to the link between the law chosen and the parties to the contract: it is perfectly legitimate to

4. For an overview of protective mechanisms in the EU Member States, see A.A.H. van Hoek and M. Houwerzijl, Complementary Study on the Legal Aspects of the Posting of Workers in the Framework of the Provision of Services in the European Union, Report to the European Commission under Contract VC/2011/0096 (2011), at 20-28; available at: <http://ec.europa.eu/social/main.jsp?catld=471 andlangld= en $>$ and $<w w w . u v a . n l / c o n t a c t / m e d e w e r k e r s / i t e m / a . a . h . v a n-h o e k . h t m l f=$ van+hoek>

5. Directive $96 / 71 / E C$ concerning the posting of workers in the framework of the provision of services, OJ 1997 L 18/1

6. Regulation (EC) No. 593/2008 on the law applicable to contractual obligations (Rome I), OJ 2008, L 177/6. For the UK, see Commission Decision of 22 December 2008 on the request from the United Kingdom to accept Regulation (EC) No. 593/2008 of the European Parliament and the Council on the law applicable to contractual obligations (Rome I) (notified under document number C(2008) 8554) OJ $2009 \mathrm{~L}$ $10 / 22-22$. Denmark is party to the Rome Convention of 1980, OJ 1998, C-27/34 (consolidated version).

7. Corrigendum to Regulation (EC) No. 593/2008 of the European Parliament and of the Council of 17 June 2008 on the law applicable to contractual obligations (Rome I), OJ 2009, L 309/87. choose a non-interest third country's law as the law applying to an international contract. The regulation does however contain some restrictions in case the contract is not truly international and/or only has links with EU Member States. In the latter case, the choice by the parties for the law of a non-EU state cannot prejudice the application of mandatory rules of EU law applicable to the case at hand. ${ }^{8}$

More restrictions are imposed in case of so-called 'weaker party' contracts. For individual employment contracts and consumer contracts a specific protection technique is used, which ensures that the weaker party can only profit from a choice of law in the contract and cannot lose any protection he or she would otherwise have enjoyed. ${ }^{9}$ Under Article $8(1)$ Rome I a choice of law by the parties may not have the result of depriving the employee of the protection afforded to him by provisions that cannot be derogated from by agreement under the law applicable in the absence of such a choice, the 'objectively applicable law'. Hence, in employment conflicts it is always relevant to ascertain the objectively applicable law, which can be done following the choiceof-law rules in Article $8(2)-8(4)$ Rome I. ${ }^{10}$ This law determines the minimum level of protection to be awarded to the internationally mobile worker. As such, it is more relevant from the point of view of regulating mobility and preventing social dumping than the freedom of choice offered by Article $8(1) .{ }^{11}$

According to Article 8(2) Rome I, in the absence of a choice by the parties, an individual employment contract shall be governed by the law of the country in which or, failing that, from which the employee habitually carries out his work in performance of the contract. The country where the work is habitually carried out shall not be deemed to have changed if he is temporarily employed in another country. In other words, the Rome I Regulation focuses on the habitual place of work in determining the applicable law. Moreover, the second sentence of paragraph 2 creates a fiction of stability of the habitual place of work in order to ensure that during a temporary posting, the law applying to the contract does not change. This posting rule applies only when the work performed in another Member State is considered to be temporary in the meaning of the provision. The preamble (paragraph 36) contains a specification of the concept of 'temporary': 'As regards individual

8. Article 3(4) Rome I Regulation

9. For insurance contracts and contracts of carriage a different technique is used: a choice of law by the parties is limited to legal systems having a specific connection to the contract: see Articles 7(3) and 5(2) Rome I.

10. Compare CJEU 15 December 2011, C-384/10, ECR I-13275 (Voogsgeerd v. Navimer), para. 28. When referring to case law, I will not include comprehensive references to literature. All case notes which are identifiable as such can be found on Eurlex - an official website of the EU. References will be to selected literature which is deemed representative of a certain position and/or is deemed particularly useful for further reference to literature in a specific country.

11. EU governments can not force the parties to the individual contract of employment to enter a choice of law into their agreement as a precondition for cross-border mobility. The standard form for seamen's contracts of the Philippines, however, does contain such a choice of law provision. See footnote 2 . 
employment contracts, work carried out in another country should be regarded as temporary if the employee is expected to resume working in the country of origin after carrying out his tasks abroad'. ${ }^{12}$ The conclusion of a new contract of employment with the original employer or an employer belonging to the same group of companies as the original employer should not preclude the employee from being regarded as carrying out his work in another country temporarily. ${ }^{13}$

Article 8(3) Rome I contains an alternative reference rule in case the country where the work is habitually carried out cannot be identified. In that case the contract shall be governed by the law of the country where the place of business through which the employee was engaged is situated.

Under Article 8(4) Rome I both pre-established connecting factors - habitual place of work and engaging place of business - may be set aside where it appears from the circumstances as a whole that the contract is more closely connected with another country, in which case the law of that other country shall apply.

\subsection{The Interpretation of Article 8 Rome I: The Case Law of the CJEU}

\subsubsection{Four Instruments, One Set of Concepts}

Article 8 of the Rome I Regulation uses the habitual place of work as its primary connecting factor and the engaging place of business as a secondary connecting factor. Currently there is no case law on the interpretation of the Rome I Regulation. However, similar criteria were used in both the rules on jurisdiction as evidenced most recently in the Brussels I Regulation ${ }^{14}$ and the Rome Convention, the treaty which preceded the Rome I Regulation. On several occasions the CJEU has stressed the continuity between the different instruments as well as the cross-referential character of concepts used therein. ${ }^{15}$ This 'transposability' of concepts is limited to cases where the provisions are similar in wording and function. Though the text of the provision in the Rome I Regulation is not identical to those in the Brussels I Regulation and the Rome Convention, this prerequisite seems to be fulfilled with regard to contracts of employment. The texts are largely identical, and all pursue a protective purpose. ${ }^{16}$ The main novelty of the Rome I Regulation - the introduction of the

12. This seems to limit the concept of posting by requiring previous employment in the country of origin as well as the intention to return there.

13. This seems to extend the notion of posting to include situations in which a contract of employment is entered into with a local employer in the host country. Compare the facts of the case in CJEU 10 April 2003, C-437/00, ECR I-3573 (Pugliese).

14. Council Regulation (EC) No. 44/2001 of 22 December 2000 on jurisdiction and the recognition and enforcement of judgments in civil and commercial matters (Brussels I), OJ 2001 L 12/1-23, Article 19.

15. Compare CJEU 7 December 2010, Joined Cases 585/08 and 144/09, ECR I-12527 (Pammer and Alpenhof) with note by the author in 1 European Review of Contract Law 93-107, at 97 (2012).

16. Compare Council Regulation (EC) No. 44/2001 of 22 December 2000 on jurisdiction and the recognition and enforcement of judgments in civil and commercial matters (Brussels I), OJ 12/1, preamble para. 13 and Regulation Rome I, preamble para. 23. country 'from which' the work is habitually performed as a (secondary) connecting factor - is explicitly based on the preexisting case law on the Brussels Convention. ${ }^{17}$ And finally, the CJEU repeatedly refers to its own case law on the old rules on jurisdiction in its judgments on both the new jurisdiction rules and the rules on applicable law. ${ }^{18}$ Hence, the interpretation of the concept 'habitual place of work' in the Rome Convention is also relevant for the interpretation of the same concept in the Rome I Regulation and the interpretation given in the context of the rules on jurisdiction is also relevant in the context of applicable law. ${ }^{19}$ As the jurisdiction regime is already quite old (the first treaty being entered into in 1968), there is ample case law on the interpretation thereof. There is far less case law on applicable law. However, of the five rulings the CJEU has given on the interpretation of the Rome Convention, three relate directly to the law applying to an individual employment contract. ${ }^{20}$ These three cases will be discussed below.

\subsubsection{The Habitual Place of Work in the Case Lam on} Furisdiction: The Country 'Where or from Which'

Under the reign of the Brussels Convention, the CJEU (then called ECJ) developed a protective rule of jurisdiction for contracts of employment within the general rules on contracts in Article 5(1). This rule attributed jurisdiction to the court for the place where the employee habitually carries out his work. ${ }^{21}$ This judge-made rule was integrated in the text of the Convention at the occasion of the accession of Spain and Portugal in $1989^{22}$ and included in a special section when the Convention was transposed into the Brussels I Regulation. In this process, the protective character of the rule remained intact, but the focus shifted from a bilateral rule aimed at Gleichlauf-giving jurisdiction to a court which could apply its own system of labour law includ-

17. $\operatorname{COM}(2005) 650$ final, p. 7

18. For an early reference, with regard to the continuity between the old case law and the new text of Article 5(1) of the Brussels Convention, see CJEU 9 January 1997, C-383/95, ECR I-57 1997 (Rutten v. Cross Medical), para. 21. For a cross-reference between the Brussels I and Rome I Regulations, see CJEU 15 March 2011, C-29/10, ECR I-1595 (Heiko Koelzsch v. Luxembourg), para. 33.

19. See more extensively on this point V. Parisot, 'Vers une coherence verticale des textes communataires en droit du travail? Réflexion autour des arrêts Heiko Koelzsch et Jan Voogsgeerd de la Cour de justice', Journal de Droit International 139, 597-645 (2012); A.A.H. van Hoek, 'Heiko Koelzsch tegen Groothertogdom Luxemburg', 60 Ars Aequi, 650-58, at 652 (2011) and the case note on Pammer (above n. 15) with references. On the issue of the interpretation method, see also E. Pataut, case note to Voogsgeerd, 101 Revue Critique de Droit International Privé 3, 647-66, at 658 (2012) with references to French literature.

20. This could be an indication of the societal relevance of the question at hand, as well as of the problems of interpretation caused by Article 6 Rome Convention/Article 8 Rome I Regulation.

21. In the case of Six Constructions v. Humbert (15 February 1989, Case $32 / 88, E C R 341)$, the ECJ refused to use to place of establishment of the employer as an alternative ground for jurisdiction in a case in which the place of work was located outside the (then) EEC because this ground of jurisdiction would not serve the protection of the worker.

22. Convention of 26 May 1989 (89/535/EEC), Article 4. A similar rule was already introduced in the Lugano Convention of 1988 (PB 1988, L 319/9). Both conventions also introduced the secondary reference to the engaging place of business. 
ing the locally applicable collective agreements ${ }^{23}$ - to a unilateral rule offering the employee easy access to a nearby court. ${ }^{24}$ To reach the desired protective result, ${ }^{25}$ the 'habitual place of work' was interpreted in a factual manner, referring to the actual performance of the contract rather than the contractual arrangements. ${ }^{26}$ Moreover, the CJEU expanded the concept to also include cases in which the worker performed activities in more than one country. According to the case law, as it currently stands, the habitual place of work does not only refer to the place in which the work is habitually performed but also to the place from which the employee principally discharges his obligations towards his employer. $^{27}$

The determination of the place of work involves a detailed assessment of facts. In case of a sales representative working in different countries, the national court should try to determine in which place the employee has established the effective centre of his working activities. ${ }^{28}$ When the employee carries out a large part of his work in the country in which he has established his office, that country is deemed to be the country in or from which the work is habitually performed. However, if a worker is sent to different locations to perform one and the same activity (cooking on oil rigs on the continental shelf for example), no such effective centre of working activities can be determined nor can any qualitative criterion be used to determine the 'essential' part of the performance. In that case, the relevant criterion for establishing an employee's habitual place of work is the place where he spends most of his working time engaged on his employer's business. ${ }^{29}$ In principle the whole duration of the contract should be taken into account, unless there is a clear intention on the side of

23. See ECJ 26 May 1982, Case 133/81, ECR 1891 (Ivenel v. Schwab) paras. 12-15; ECJ 15 January 1985, Case 266/85, ECR 239 (Shenavai v. Kreischer) para. 16; ECJ 15 February 1989, Case 32/88 ECR 341 (Six Constructions v. Humbert) para. 10 and CJEU 13 July 1993, C-125/92 (Mulox IBC v. Geels) para. 15

24. CJEU 13 July 1993, C-125/92 (Mulox IBC v. Geels) para. 19. CJEU 27 February 2002, C-37/00, ECR 2002, I-2013 (Weber v. Universal Ogden Services), para. 40. It is interesting to note that these changes did not deter the CJEU from referring to the old case law for the interpretation of the current text.

25. On the protective character of the interpretation given to the rules on jurisdiction, see Parisot 2012, above n. 19, at 620. For a cricical analysis thereof, see U. Grušić, 'Jurisdiction in Employment Matters under the Brussels I Regulation: A Reassessment', 61 International and Comparative Law Quarterly 1, 91-126 (2012).

26. See for example CJEU 27 February 2002, C-37/00, ECR I-2013 (Herbert Weber v. Universal Ogden Services $L t d$ ) para. 58 and A. Winterling, Die Entscheidungszuständigkeit in Arbeitssachen im europäischen Zivilverfahrensrecht 2005, at 61-62.

27. CJEU 13 July 1993, C-125/92 (Mulox IBC v. Geels), paras. 20 and 26 Compare CJEU 10 April 2003, C-437/00, ECR 2003, I-3573 (Pugliese), para. 19 which refers to the place where or from which the employee in fact performed the essential part of his duties towards his employer. Neither the text of the Brussels Convention (as changed by the Convention of 1989) nor the text of the Brussels I Regulation contain a reference to the place from which the work is habitually performed.

28. CJEU 9 January 1997, C- 383/95, ECR 1997, I-57 (Rutten v. Cross Medical), para. 23.

29. CJEU 27 February 2002, C-37/00, ECR 2002, I-2013 (Weber v. Universal Ogden Services), para. 50. both parties to change the place of work, in which case only the most recent place of work will be relevant. ${ }^{30}$

\subsubsection{The Hierarchy betmeen the Habitual Place of Work and the Engaging Place of Business: Koelzsch and Voogsgeerd}

The extensive interpretation which the CJEU has given to the concept of 'habitual place of work' in the context of the rules on jurisdiction is continued in the case law on the Rome Convention. In two cases the CJEU dealt with the identification of the place of work in international transport (by road and sea, respectively). These cases are of particular interest as the applicable law to employment in the transport sector is traditionally linked to the place of establishment of the employer and/or the flag of the vessel on which the work is performed. ${ }^{31}$ In the Commission's proposal for the Rome I Regulation, the introduction of the place from which the work is performed in the connecting factor was deemed to be particularly relevant for personnel working on board aircraft. ${ }^{32}$ However, the explanatory memorandum was not conclusive as to whether the extensive interpretation was already deemed to be valid under the Rome Convention nor on the applicability of the extended rule to other modes of transportation.

In the Koelzsch and Voogsgeerd cases, the CJEU basically rejects the primacy of the traditional connection to the place of establishment of the employer while totally ignoring the flag as a relevant factor. ${ }^{33}$ The court stresses that the reference to the engaging place of business in the Rome Convention is strictly secondary. ${ }^{34}$ Even in the case of a truck driver working in international transport (Koelzsch) or a sailor working on a seagoing vessel (Voogsgeerd), the national court should try to establish whether, based on the circumstances as a whole, a country can be identified where or from which the work is

30. Id., paras. 52-54

31. O. Deinert, Internationales Arbeitsrecht, Tübingen, Mohr Siebeck 2013, $165 \mathrm{ff}$.; Parisot, above n. 19, at 624. See for a discussion of this issue in the context of the liberalization of the transport markets in the EU: A.A.H. van Hoek, 'Het toepasselijk recht op arbeidsovereenkomsten - Een reactie op het Groenboek EVO', Paper submitted to the European Commission <http://ec.europa.eu/justice/newsroom/civil/ opinion/040127_en.htm>, published in Sociaal Recht, at 365-79 (2003) with references.

32. $\operatorname{COM}(2005) 650$ final, p. 7

33. In the Voogsgeerd case no mention is made of the flag(s) of the ships on which Voogsgeerd performed his work. Admittedly, the flag was not brought forward as a relevant connecting factor by any of the parties to the procedure. Neither was the connection to the habitual place of work, though. See on this issue P. Winkler von Mohrenfels, 'Zur objektiven Anknüpfung des Arbeitsvertragesstatuts im internationalen Seearbeitsrecht: gewöhnlicher Arbeitsort, Flagge und einstellende Niederlassung', 5 Europäische Zeitschrift für Arbeitsrecht, 368-80, at 373-77 (2012); U. Grušić, 'Should the Connecting Factor of the "Engaging Place of Business Be Abolished in Private International Law?', 62 International and Comparative Law Quarterly 173-92, at 180-81 (2013) and A.A.H. van Hoek, 'Het toepasselijk recht op arbeidsovereenkomsten in de zeevaart - Een commentaar op HvJ EU 15 december 2011, case C-384/10, Voogsgeerd/Navimer', 7 Nederlands Tijdschrift voor Europees Recht 245-51 (2012).

34. CJEU 15 March 2011, C-29/10, ECR 2011, I-01595 (Koelzsch v. Luxembourg), and CJEU 15 December 2011, C-394/10, ECR I-13275 (Voogsgeerd v. Navimer) and in particular Voogsgeerd, paras. 34-35. Compare also above n. 21 
actually performed. ${ }^{35}$ The CJEU justifies this broad interpretation of the primary connecting factor by referring to the protective character of the provision on the law applying to individual contracts of employment: 'It follows that, in so far as the objective of Article 6 of the Rome Convention is to guarantee adequate protection for the employee, that provision must be understood as guaranteeing the applicability of the law of the State in which he carries out his working activities rather than that of the State in which the employer is established. It is in the former State that the employee performs his economic and social duties and, as was noted by the Advocate General in point 50 of her Opinion, it is there that the business and political environment affects employment activities. Therefore, compliance with the employment protection rules provided for by the law of that country must, so far as is possible, be guaranteed'. ${ }^{36}$ When ascertaining the place of work in case of international transport (including international shipping), the national courts must take account of all the factors which characterise the activity of the employee. These are, in particular, the place from which the employee carries out his transport tasks, receives instructions concerning his tasks and organises his work and the place where his work tools are situated. ${ }^{37}$ Additionally, the court must determine the places where the transport is principally carried out, where the goods are unloaded and the place to which the employee returns after completion of his tasks. ${ }^{38}$ Only when it is not possible to identify the country in or from which the work is habitually performed, recourse may be had to the second connecting factor, the engaging place of business. ${ }^{39}$ For the determination of the latter place, the situation at the time of recruitment is relevant, not the actual performance of the contract. ${ }^{40}$

\subsubsection{The Closer Connection: Schlecker}

In the Voogsgeerd case the CJEU seems to be aware of the fact that the place in which the engaging place of business is situated may not present a relevant connecting factor from a socio-economical point of view. ${ }^{41}$ In this context, the court refers to the possibility to ignore

35. CJEU 15 March 2011, C-29/10, ECR 2011, I-01595 (Koelzsch v. Luxembourg), paras. 47-49.

36. Id., para. 42

37. CJEU 15 March 2011, C-29/10, ECR 2011, I-01595 (Koelzsch v. Luxembourg), paras. 48-49, CJEU 15 December 2011, C-394/10 (Voogsgeerd v. Navimer), para. 38.

38. CJEU 15 March 2011, C-29/10, ECR 2011, I-01595 (Koelzsch v. Luxembourg), paras. 48-49. CJEU 15 December 2011, C-394/10, ECR I-13275 (Voogsgeerd v. Navimer), paras. 38-39.

39. CJEU 15 December 2011, C-394/10, ECR I-13275 (Voogsgeerd v. Navimer), paras. 32-35

40. The identification of the habitual place of work is left to the national courts. But in both the Koelzsch and the Voogsgeerd cases it is clear from the facts of the case that there was no relevant link between the actual performance of the contract by the employee and the country of establishment of the employer. The German truck-driver operated from Germany, the Dutch sailor from Antwerp (BE); both were employed by a Luxembourg company.

41. As I am mainly interested in the socio-economic, regulatory function of the conflicts-rule, I will not discuss the connection to the engaging place of business in any detail. See on this issue: Grušić, above n. 33 at 190. the presumptions referring to the habitual place of work and the engaging place of business when based on an assessment of the circumstances of the case, the national court finds the contract to be more closely connected to another country. The possibility to use this 'escape clause', which is currently regulated in Article 8(4) Rome I, was the object of the most recent preliminary question regarding the law applying to individual employment contracts which was answered in the Schlecker case. ${ }^{42}$

The Schlecker case concerned a conflict between a German employee (Ms Boedeker) and her German employer (the Schlecker company), caused by the decision of the employer to terminate employment in the Netherlands and re-instate the employee in a different position in Germany. For the last twelve years (of a total of twenty-seven years of service), the employee had been employed as manager of the Dutch division of the employer, supervising its 300 local branches. There was no contestation as to the fact that the Netherlands was the habitual place of work. ${ }^{43}$ The employee relied on the application of Dutch law, which in this case offered her better protection than German law. However, the employer claimed that the contract was more closely related to Germany. Elements referring to Germany where inter alia the nationality and place of domicile of both parties, the language and original currency of the contract, reference to provision of German law in the contract and the fact that the employee was covered by German tax law, social security and additional pension schemes. Could the Dutch court in this case ignore the connection based on the place of work in favour of German law?

In the Dutch case which led to the preliminary question, Advocate General Strikwerda had stressed the protective character of using the habitual place of work as the primary connecting factor. Due to this specific character, the advocate general concluded that the escape clause based on a closer connection should be used sparingly when used in competition with the habitual place of work. ${ }^{44}$ This view seems to be supported by the employee, Austria and the European Commission in their submissions to the CJEU. ${ }^{45}$ The employee also claimed that the escape clause of Article 8(4) Rome I should be used to apply the law most favourable to the employee. In contrast, the Dutch government favoured an interpretation in which also in this case the law of the habitual place of work may be replaced by a law that is more closely connected to the contract at hand.

In its judgment the CJEU sides with the Dutch government. The habitual place of work does take priority over

42. CJEU 12 September 2013, C-64/12 (Schlecker v. Boedeker), nyr.

43. Id., para. 27.

44. For a similar position, see L. Merrett, Employment Contracts in Private International Law (2011), at 206 and 209. For the original judgment, see Dutch Supreme Court (Hoge Raad) 3 February 2012, Case No. 10/01806, ECLI:NL:HR:2012:BS8791 (available at: <www.rechtspraak. $\mathrm{nl}>$ ), Nederlandse Jurisprudentie (2012), 90.

45. CJEU 12 September 2013, C-64/12 (Schlecker v. Boedeker), nyr, para. 19. 
the engaging place of business, based on the protective character of the first connecting factor. No such hierarchy exists, however, with regard to the escape clause referring to the closest connection. Though the national court must first determine the applicable law by reference to the pre-established connecting factors, it is for the national court to disregard these connecting factors and to apply the law of another country, where it is apparent from the circumstances as a whole that the employment contract is more closely connected with that country. Both connecting factors are put on the same footing in this regard. ${ }^{46}$ The court does, however, specifically reject the assumption that the escape clause may be used to offer better protection to the employee. ${ }^{47}$ The closer connection test cannot be performed by simply counting connecting factors: not all connecting factors carry the same weight. According to the CJEU 'among the significant factors suggestive of a connection with a particular country, account should be taken in particular of the country in which the employee pays taxes on the income from his activity and the country in which he is covered by a social security scheme and pension, sickness insurance and invalidity schemes. In addition, the national court must also take account of all the circumstances of the case, such as the parameters relating to salary determination and other working conditions.' 48 The content of the relevant laws is not decisive in this matter.

Accordingly, the primacy given to the habitual place of work in Article 8(2) Rome I is meant to ensure that employees enjoy the levels of protection that prevail in their socio-economic environment. Article 8 Rome I as a whole however seems to be based on the closest connection rule. ${ }^{49}$

\subsection{Some Problems and Controversies as to the Application of Article 8 Rome I}

\subsubsection{The Principles Underlying Article 8 Rome I}

The preamble to the Rome I Regulation contains several indications as to the principles underlying the system of conflict rules contained therein. In general, the regulation aims to ensure predictability of the outcome of litigation and certainty as to the law applicable to a contractual obligation. Both goals are served by decisional harmony: a situation in which the same choice-oflaw result is reached in all Member State courts. ${ }^{50}$ In order to achieve decisional harmony, the rules contained in the regulation should be highly foreseeable, while retaining a certain degree of flexibility. ${ }^{51}$

Party autonomy is deemed to be one of the cornerstones of the system. However, parties regarded as weaker are

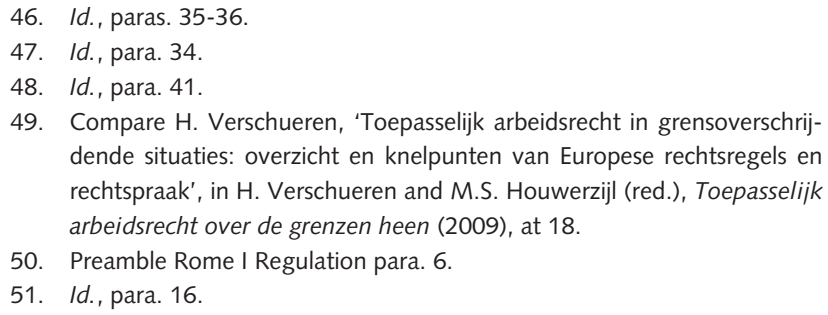

protected by special conflict-of-law rules that are more favourable to their interests. ${ }^{52}$ This means inter alia that employees should not be deprived of the protection afforded to them by provisions that are mandatory or unilaterally binding on the employer. ${ }^{53}$ This poses a restriction on the effect of a choice of law by the parties. However, the preamble contains no information as to the way the special protection of employees affects the law applicable in the absence of such a choice.

\subsubsection{Adequate or Better Protection?}

One point of discussion is whether Article 8 Rome I Regulation allows the court to take into account which law is most favourable to the employee. In other words, does the Rome I Regulation strive for (merely) adequate protection of workers or (rather) better protection? With regard to the meaning of Article $8(1)$ Rome I, the majority opinion seems to hold that the law chosen by the parties applies to the contract in full, except when mandatory rules of the otherwise applicable law would provide the worker better protection. ${ }^{54}$ In the latter case, the employee will be protected by the law which offers the better protection. In choice-of-law terms, the favorprinciple informs the application of paragraph $1 .{ }^{55}$

In contrast, the more favourable law argument does not seem to be relevant for the outcome of the choice-of-law consideration under Article 8(2)-(4) Rome I. ${ }^{56}$ Which country is deemed to be the country in or from which the work is habitually performed should be assessed on an objective basis; the protection offered by the systems involved should not influence the outcome of this consideration. A similar argument is put forward with regard to the establishment of a closer connection under Article 8(4) Rome I. Though occasionally authors have proposed to use the 'escape clause' to apply the law

52. Id., paras. 11 and 23

53. Id., para. 35

54. AG Trstenjak, Opinion to Voogsgeerd, para. 48; AG Wahl, Opinion to Schlecker para. 24; Deinert, above n. 31 at 96, Rn 2, 102, Rn 13 and 128 Rn 62; Merrett, above n. 44 at 215; P. Mankowski and O.L. Knöfel, 'On the Road Again oder: wo arbeitet ein Fernfahrer', 4 Europäische Zeitschrift für Arbeitsrecht 521-36, at 524 (2011); Winkler von Mohrenfels, above n. 33 at 371 . The opposing view would grant a choice of law in a contract of employment only substantive effect - comparable to the effect of a choice of law in non-international contracts under Article 3 para. 3. See inter alia L. Strikwerda, Inleiding tot het Nederlandse internationaal privaatrecht (2012), at 173, para. 175. This would mean that the chosen law only applies in as far as it doesn't deviate from mandatory provisions of the otherwise applicable law. The CJEU has not taken up a clear position on this issue yet, see Koelzsch, para. 35 and Voogsgeerd, para. 28.

55. I will not deal extensively with the discussion as to the exact interpretation and application of Article 8(1) as this issue is of minor relevance for the specific focus of this article - which is the regulatory function of private international law.

56. See on the majority opinion, AG Wahl, Opinion to Schlecker, paras, 32 , 36-37; Deinert, above n. 31 at 122, Rn 50; 131 Rn 68; 155 Rn 128 with references and $161 \mathrm{Rn} 143$. 
which offers the best protection to employees, ${ }^{57}$ this point of view is specifically rejected by the CJEU in the Schlecker case. The favor-principle is only to be used in the context of a choice of law by the parties.

\subsubsection{Adequate Protection and the Relative Weight of the Habitual Place of Work}

But the controversy does not end with this conclusion. The Schlecker case brought to the fore that different agents may hold quite divergent views on the concept of 'adequate protection'. In the Koelzsch and Voogsgeerd cases, the CJEU stressed that the rules on applicable law should submit the contract of employment to the law of the state in which the employee performs his economic and social duties because it is in this country that the business and political environment affects employment activities. In jurisprudence this mechanism, in which certain weaker parties are protected by applying the law of their social and economic environment, is referred to as the 'protection principle' or 'functional allocation'. This terminology is common in Dutch private international law, ${ }^{58}$ which may explain the position of the Dutch Advocate General Strikwerda in the Schlecker case. In Dutch legal writing, the reference to the locus laboris in Article 8(2) Rome I Regulation is seen as the embodiment of the protective character of the choiceof-law rule. Accordingly, a deviation from the locus laboris rule in cases in which the social and economic environment of the employment can be clearly established can be deemed to counteract the protective function of the rule. ${ }^{59}$

In his opinion before the CJEU, Advocate General Wahl takes a totally different view on the protective character of Article 8 Rome I. Protection is given mainly by limiting the freedom of the parties to choose the applicable law. ${ }^{60}$ If any protection is to be had from the choice of law rules that apply in the absence of such a choice, it consists of a strict adherence to the proximity rule.$^{61}$ In this view, the employee is protected by applying the law that is most familiar to her. Which in the case of Ms Boedeker (the employee in the Schlecker

57. See for example V. van den Eeckhout, 'Navigeren door artikel 6 EVOverdrag c.q. artikel 8 Rome I-Verordening: mogelijkheden tot sturing van toepasselijk arbeidsrecht', 9 Arbeidsrechtelijke Annotaties, at 55 (2010) and 'Enkele beschouwingen naar aanleiding van diverse recente Europese en Nederlandse uitspraken in het internationaal arbeidsrecht (Koelzsch, Voogsgeerd, Vicoplus, Nuon-rechtspraak en de zaak FNV/De Mooij). Welke (nieuwe) argumentatiemogelijkheden voor werknemers tot opeisen van (meer) arbeidsrechtelijke bescherming in internationale situaties?', ARBAC (<www.arbac.nl>) (2012). Some authors have commented that a certain element of 'favor' may be applied in practice, especially when the lex fori is also the more favourable law: see Deinert, above n. 31, at 155-56, Rn 128 and 130 and Pataut (2012), above n. 19 , at 660-61.

58. See in particular Th.M. de Boer, 'The Purpose of Uniform Choice of Law Rules: The Rome II Regulation', 56 Netherlands international Law Review, 295-332, at 298 and 316 (2009) and Th.M.de Boer, 'The EEC Contracts Convention and the Dutch Courts: A Methodological Perspective', 54 Rabels Zeitschrift 25-62 (1990).

59. This seems to be the French position as well: Deinert, above n. 31, at $156 \mathrm{Rn} 129$.

60. Opinion delivered on 16 April 2013, para. 25

61. Id., para. 26 case) would be the law of her country of origin and domicile, rather than her country of work. Advocate General Wahl even argues that the protection of the employee is served by an extensive interpretation of the escape clause, because in that case the search for the closest connection is given precedence over legal certainty and predictability.

Hence, the two Advocates General adhere to strongly diverging views on the effect of the alleged protective character of Article 8 Rome I on the interpretation of its provisions. Moreover, they reach opposing conclusions as to the desirability to deviate from the law of the habitual place of work. ${ }^{62}$ Advocate General Wahl seems to adhere to a classic pattern in which the choice-of-law rules are geared to protect outgoing expatriates against the lower level of protection offered by the states to which they are posted.$^{63}$ Moreover, the broad use of the closer connection rule emphasises the individual character of the choice-of-law process. The priority given by Advocate General Strikwerda to the country of work emphasises the collective element of protection of workers and fits into a trend focusing on equal protection of all workers on the labour market of a given state - a trend which is very present in the discussion on intraEU migration and the posting of workers. ${ }^{64}$ The Schlecker case feeds directly into this debate.

In the Koelzsch and Voogsgeerd cases, the CJEU stressed the priority of the habitual place of work over the place

62. V. van den Eeckhout, De ontsnappingsclausule van artikel 6 lid 2 slot EVO Verdrag (artikel 8 lid 4 Rome I Verordening). Hoe bijzonder is de zaak Schlecker? (2013), 5-8, Paper available at: <http://papers.ssrn. com/sol3/papers.cfm?abstract_id=2364358>. This difference may also embody the controversy between flexibility and justice in the individual case on the one hand versus legal certainty and predictability on the other - compare Deinert, above n. 31 at 156 Rn 131. In the Commission proposal for the Rome I Regulation, $\operatorname{COM(2005)650final,~the~}$ proper law escape was deleted from Article 4, as a means to foster legal certainty in the internal market. However, the escape clause was reintroduced in the legislative process and is part of the final version of Article 4 of the regulation. The Commission did not propose to remove the escape clause from the provision on employment contracts. In the final text of the Rome I Regulation, deviation from the standard connecting factor is mandated when there is a closer connection to another country in case of employment contracts. Article 4 of the same requires a manifestly closer connection.

63. In para. 43 of his conclusion, the AG gives the example of a French employee of a French company who is posted in Saudi Arabia for a period of ten years. P. Stone (EU Private International Law (2010), at 358) even suggests a 'discriminatory' reading of Article 8(4) in which the escape clause is used liberally when European employees are posted to non-EU countries but sparingly in case of posting within the EU. Compare J.H. Even, ‘Het toepasselijke recht op arbeidsovereenkomsten. Artikel 6 EVO en 8 Rome I steeds verder ontrafeld', 1 Nederlands Internationaal Privaatrecht 13-24 (2013); P.R. Beaumont and P.E. McEleavy (A.E. Anton's Private International Law (2011), at 535) describe a similar intention informing the international scope rule of UK statutes. Compare on this issue also A.A.H. van Hoek, Internationale mobiliteit van werknemers, een onderzoek naar de interactie tussen arbeidsrecht, EGrecht en IPR aan de hand van de detacheringsrichtlijn (2000), at 230 and 296-97.

64. See below and EU Procedure file 2012/0061/COD, inter alia the debate in Council of $21 / 6 / 2012$ and $6 / 12 / 2012$. It is interesting to note that already in the 1972 proposal of the European Commission on the law applicable to intra-EU labour mobility (OJ 1972, C 49/26) the place of work played a predominant role and the possibility to deviate from application of the lex loci laboris was limited to specific situations. 
of establishment of the employer. The latter place may not have a real and relevant connection to the actual performance of the work, especially as within the EU the employer enjoys freedom of establishment and free movement services. As a result, within the EU, the place of establishment of a transport company does not have to bear any relation to the place where the transport services are actually performed. Cheap airlines are a case in point, but transport by road also gives rise to 'flags of convenience'. By focusing on the effective performance of the contract of employment, the CJEU seems to counter the negative effects the employers' freedom of establishment may have on the protection of the employee. ${ }^{65}$ Moreover, by specifically denying any priority for the place of establishment of the employer, the court implicitly rejects the existence of a home country control rule with regard to contracts of employment. $^{66}$

However, by given a broad interpretation of the possibility to deviate from the law of the habitual place of work in favour of another law, the CJEU seems - to a certain extent - to undo the effect of the decisions in Koelzsch and Voogsgeerd. The escape rule of Article 8(4) undermines the general applicability of the law of the habitual place of work. Based on the criteria which are deemed to be relevant in establishing a closer connection, this other law will usually be the law of common origin. ${ }^{67}$ Accordingly, in effect the rule established by the CJEU in the Schlecker case (when interpreted extensively) may be quite similar to a home country control rule. $^{68}$ This highly political aspect is, however, not reflected in the judgment of the CJEU, which squarely sides with Advocate General Wahl. ${ }^{69}$

\subsubsection{The Circumstances of the Case}

Both the determination of the habitual place of work under Article 8(2) Rome I and the establishment of a closer connection under Article 8(4) Rome I may require a comprehensive assessment of facts. Whereas the place of work is established on the basis of the facts regarding the performance of the contract, the closer connection also relies on other factors, such as the tax and social insurance position of the worker and the contractual arrangements made by the parties. With this

65. Compare Mankowski and Knöfel, above n. 54, at 526; Pataut, above 19, at 663-64. Parisot (above n. 19 at 628) seems more neutral about the using the establishment of the employer as a connecting factor. This argument is elaborated by the current author (with references) in Van Hoek, Ars Aequi, above n. 19, at 653-54 and 656.

66. The ruling of the CJEU in the Viking case (11 December 2007, C-438/05, ECR I-10779) suggested otherwise. See more extensively on this issue (with references): A.A.H. van Hoek and M.S. Houwerzijl, 'Loonconcurrentie als motor van de interne markt? Een tweeluik - Deel 1: De arresten Viking, Laval en Rueffert, verdragsaspecten', 14:7/8 Nederlands tijdschrift voor Europees Recht, 190-205.

67. Compare Regulation 883/2004, OJ 2004 L 166/1, Articles 11(3)(a), 12(1) and 16(1).

68. This is particularly true in cases in which employer and employee do have a common origin. Cases of 'irregular posting' may not demonstrate this fact pattern. See Van Hoek and Houwerzijl, above n. 4, at 75.

69. On the wider political aspects of the Rome I Regulation, see P. Mankowski, Interessenpolitik und europäisches Kollisionsrecht. Rechtspolitische Überlegungen zur Rom I- und zur Rom II-Verordnung (2011). strong reliance on the circumstances of the case, the CJEU takes position in the eternal tension between flexibility and certainty in choice of law. Again, this choice is not without contestation.

With regard to the habitual place of work, the CJEU justifies its decision on the basis of the protection of the worker. Even the mobile employee should be protected by a law which has a real and relevant connection to the factual performance of his work. The merits of this approach are described in the previous paragraph. However, the position of the CJEU also has considerable drawbacks. Whereas the engaging place of business of the employer usually offers a clear-cut, easy-to-apply connecting factor, ${ }^{70}$ the habitual place of work can be a source of fierce contestation. In the Koelzsch case, the Advocate General refers to the need to study the duty roster (Körselsrapport) in order to assess the exact time and place of work. In reality, things may even be more complicated than that when official rosters do not match the actual deployment of the workers. This raises complex issues of civil procedure: who bears the procedural risk and the burden of proof as regards the connecting factors of private international law? ${ }^{71}$ Moreover, due to the factual character of the assessment, different courts may reach different conclusions in similar cases, which reduces legal certainty. ${ }^{72}$ In Belgium, different courts have reached contrary conclusions as to the question of whether Ryan Air pilots deployed from Charleroi, Belgium, can be deemed to habitually work in or from Belgium. ${ }^{73}$ The issue is similarly contested in France, despite the firm position of the French government as to the 'French' character of work performed from the local bases of low-cost foreign airlines. ${ }^{74}$

Problems relating to the exact operationalisation of the concept of 'habitual place of work' in the case of transport by air may be solved in time, when the criteria for assessing the place of work in that particular sector of the labour market become more clearly established. The problems in road transport may be more persistent inter

70. Parisot, above n. 19 at 630. Contra: Grušić, above n. 33.

71. Mankowski and Knöfel, above n. 54, at 534 with references.

72. Parisot, above n. 19, at 637 ff; Th.M. de Boer, 'Note to Weber', 337 Nederlandse Jurisprudentie (2005). In his Opinion in the Weber case, C-37/00, delivered on 18 October 2001, AG Jacobs already identified the need for extensive factual information when assessing the place of work in cases such as the Weber case.

73. Verschueren, above n. 49, at 21; Judgments adhering to the airport as local base: Arbeidsrechtbank Charleroi (Labour Court) 21 March 2005, JTT 2005, 264 and Arbeidshof (Court of Appeal) Brussel 10 June 2008, 3 Tijdschrift@ipr.be (2008), 44 v. judgments denying a locus base in Belgium Arbeidshof Bergen (Court of Appeal) 7 September 2007, JLMB 2007, 1512 and Arbeidsrechtbank Charleroi 4 November 2013 (unpublished). For comments on the latter case, see Van Calster, <http:// gavclaw.com/2013/11/13/ceci-nest-pas-une-base-ryanair-the-court-incharleroi-on-place-where-the-employee-habitually-carries-out-his-work/> and <www.cne-gnc.be/cmsfiles/file/A/CNE/PRESSE/2014-01-21\%20 COMMUNIQUE\%20DE\%2OPRESSE\%20Ryanair\%20paie\%20ses \%20lois\%20sociales\%20en\%20Belgique.pdf>; <www.cne-gnc.be/cms files/file/A/CNE/PRESSE/2013-11-08\%20COMMUNIQUE\%2ODE \%20PRESSE \%20Ceci\%20n'est\%20pas\%20une \%20base \%20Ryanair. pdf $>$.

74. Parisot, above n. 19, at 643-44. See also <www.telegraph.co.uk/finance/ newsbysector/transport/10350997/Ryanair-to-appeal-6.7m-fine-forbreaking-French-labour-laws.html>. 
alia because of the more individualistic character of the work performance: truck drivers do not operate in crews and are not bound to a very specific infrastructure (airports, seaports) for the start and finish of the transport activity. ${ }^{75}$ This does not only cause problems of proof, but may also lead to a more individualised protection of the workers involved. Due to the purely secondary relevance of the engaging place of business, it is no longer evident that all workers employed by a single transport company are covered by the same law. ${ }^{76}$ In transport by road, even a common base from which a group of workers (a 'crew') is employed, might be missing. This strict individualisation of the applicable law (and hence employment conditions) can seriously hamper the possibility for the workers to protect their interests in a collective manner. But the individual character of the assessment may also make other, administrative and collective, modes of protection and enforcement more problematic. ${ }^{77}$ In this respect, the purely individual contractual approach of private international law may be at odds with a regulatory approach in which individual private law protection is closely interrelated with public law and collective modes of protection.

\subsection{The Limited Relevance of the Lex Causae}

In the private international law debate a lot of emphasis is placed on the interpretation of the connecting factors in the choice-of-law rule of Article 8 Rome I. However, the law applying to the employment contract as such is only one aspect of workers' protection. ${ }^{78}$ As discussed in the introduction, within the EU local protection for foreign workers is no longer a part of the law of migration. But the country where the work is actually performed may try to set certain standards for all work performed within the territory by other means. Many rules of labour protection carry administrative or criminal sanctions and are supervised by labour inspectorates. The rules may be directed to the employer but also to the overseer of the workplace or the main contractor, independent of any direct contractual relationship with the

75. Compare Hof Den Bosch (Court of Appeal) 28 May 2013, ECLI:NL:GHSHE:2013:CA1457, JAR 2013/159, RAR 2013/160 (Mooy) and Hof Den Bosch (Court of Appeal) 10 April 2007, ECLI:NL:GHSHE: 2007:BB2826, NIPR 2007, 292.

76. Merrett, above n. 44, at 176 describes the importance attached under English common law to the application of one and the same law to all workers employed by a single employer in a single location. This was deemed to be a matter of equality. Also the right to choose the applicable law to the individual contract is assessed critically against this need for equal treatment (id. at 214). The importance of a single law applying to the entire workforce of a undertaking is also mentioned specifically by Mankowski and Knöfel, above n. 54, at 525 .

77. See for a more detailed discussion on the relevance of public law and collective methods of protection: A.A.H. van Hoek and M.S. Houwerzijl, Comparative Study on the Legal Aspects of the Posting of Workers in the Framework of the Provision of Services in the European Union (2011), Report to the European Commission under contract VT/ 2009/0541 (2011), at 21. To be found at: <http://ec.europa.eu/social/ main.jsp?catld $=471$ andlangld=en $>$. See on the impact of collective labour law on the choice of law position taken by individual authors, Van Hoek, above n. 63, at 226-27

78. See inter alia P. Mankowski, 'Die Rom I-Verordnung - Änderungen im europäischen IPR für Schuldverträge', $4 I H R$, at 146 with references (2008). workers concerned. Likewise, the unions in the host state may try to protect posted workers by persuading the employer to enter into a collective agreement on their behalf. These rules do not fit nicely into the private international law scheme. The concept which offers most potential in this respect is that of 'overriding mandatory provisions' as regulated in Article 9 Rome I. To fully understand the possibilities and limits of Article 9 Rome I within the internal market, Article 9 will have to be placed in the context of the right of free movement of services. Both will be done in the next section.

\section{Article 9 Rome I, the Free Movement of Services and the PWD}

\subsection{Overriding Mandatory Provisions in Article 9 Rome I}

Article 9 Rome I Regulation contains a clause on overriding mandatory provisions. According to its first paragraph, 'Overriding mandatory provisions are provisions the respect for which is regarded as crucial by a country for safeguarding its public interests, such as its political, social or economic organisation, to such an extent that they are applicable to any situation falling within their scope, irrespective of the law otherwise applicable to the contract under this Regulation.' The predecessor of the Rome I Regulation, the Rome Convention, contains rules on overriding mandatory provisions in its Article 7. Though the provisions are not identical, the concept 'of overriding mandatory provisions' in both provisions may be equated. ${ }^{79}$

The interpretation of Article 7 of the Rome Convention was addressed in the recent Unamar case. ${ }^{80}$ In this case the CJEU was asked whether the Belgian rules on the protection of commercial agents qualified as overriding mandatory provisions and, if they did, whether EU law would allow application of those rules to agency contracts that where otherwise governed by the law of another EU Member State. ${ }^{81}$ In its judgment, the CJEU allowed the courts of the Member States discretion to override the otherwise applicable law in favour of mandatory provisions of forum law in so far as it appears that the national legislature adopted the latter provisions in order to protect an interest judged to be essential by the Member State concerned. ${ }^{82}$ It can be inferred from the case law that the protection of agents could well be such an essential interest. ${ }^{83}$ Likewise, it is to be expected

79. Beaumont and McEleavy, above n. 63 , at 508

80. CJEU 17 October 2013, C-184/12 (Unamar), nyr. Case note: E.J.A. Franssen, 302 Jurisprudentie arbeidsrecht (2013), 302 (NL).

81. The case is complicated by the fact that the Belgian law is in part based on a European directive but extends the protection of the agent in several ways. The relevant aspect here, was that the Belgian law also applies to agents who trade in services rather than goods (a category that falls outside the scope of the EU directive).

82. CJEU 17 October 2013, C-184/12 (Unamar), nyr, para. 50.

83. See CJEU 9 november 2000, C-381/98, ECR 2000 I-09305 (Ingmar). 
that the protection of workers, in principle, could be deemed to have an overriding mandatory character. ${ }^{84}$ An indication thereof can be found in the fact that the formulation of Article 9(1) Rome I was taken for the Arblade case of the CJEU, a case which specifically dealt with Belgian protective labour standards. ${ }^{85}$

Many labour law rules have an overriding mandatory character, though the Member States traditionally draw the line between lex causae rules and overriding mandatory provisions differently. ${ }^{86}$ In Germany and the Netherlands a distinction was made between rules that offer mandatory contractual protection to a weaker party (which were deemed to be part of lex causae) and rules which have a public law character and/or protect a public interest (which had an independent scope of application). The two legal systems advocated a strict division between the two categories: a rule would either totally depend on the choice-of-law rule for its application or have an independent scope rule which would determine its international application in an exclusive manner. ${ }^{87}$ Belgium and France employed a much wider notion of lois de police, under which most of their mandatory labour protection would apply to work performed within the territory. However, to some extent, the same rules could also apply to contracts performed in another country, as long as they were governed by Belgian or French law. Accordingly, the division between the two types of rules was less strict. ${ }^{88}$ In England a strict division was made between common law protection (part of lex causae) and protective statutes having their own scope of application. ${ }^{89}$ The Unamar decision seems to leave room for these differences - at least to some extent. ${ }^{90}$ However, the judgment also makes clear (once again) that within the internal market, the application of

84. Workers' protection has been recognized in the case law on the internal market as an overriding public interest which may justifies obstacles to the free movement of services and the freedom of establishment. See for example ECJ 23 November 1999, C-369/96, ECR 1999, I-8453 (Arblade) and ECJ 10 December 2007, C-438/05, ECR 2007, I-10779 (Viking).

85. ECJ 23 November 1999, C-369/96, ECR 1999, I-8453 (Arblade).

86. Beaumont and McEleavy, above n. 63, at $511 \mathrm{ff}$. For a description of the different models of workers' protection in the EU Member States, see Van Hoek and Houwerzijl, above n. 4, at 22.

87. For Germany, see Deinert, above n. 31 at 186 and J. Nojack, 'Exclusivnormen im IPR', Studien zum ausländischen und internationalen Privatrecht 152 (2005), at 107 ff.; for the Netherlands, see Strikwerda, above n. 54, at 67-68 and Paul Vonken (ed.), Asser-Serie, International privaatrecht Deel I - Algemeen deel IPR (2013), at 406 and 412

88. For Belgium, see A. Van Regenmortel, 'Openbare orde en dwingend recht: een confrontatie tussen de Europese en de Belgische invulling', in H. Verschueren and M.S. Houwerzijl (eds.), Toepasselijk arbeidsrecht over de grenzen heen (2009), at 91-158, $120 \mathrm{ff}$.

89. Beaumont and McEleavy, above n. 63, at $113 \mathrm{ff} . ;$ Merrett, above n. 44 , at $242 \mathrm{ff}$.; L. Merrett, 'The Extra-Territorial Reach of Employment Legislation', 4 Industrial Law Journal 355-81 (2010); U. Grušić, 'The Territorial Scope of Employment Legislation and Choice of Law', 75 Modern Law Review 5, 722-51 (2012); Stone, above n. 63, at 359.

90. Mankowski, above n. 78, at 146-47. The English position seems most problematic, as the distinction is based on legislative technique rather than on policy grounds. See the authors cited in the previous note. overriding mandatory provisions has to be in conformity with the rules on free movement. ${ }^{91}$

\subsection{Free Movement of Services and the Application of Host State Rules to Posted Workers}

The application of overriding mandatory provisions of the lex fori to contracts governed by foreign law does not only compromise the harmonising effect of the Rome I Regulation, ${ }^{92}$ it may also obstruct the market freedoms, in particular the free movement of services as protected by the TFEU. With regard to labour law, this has been specifically acknowledged in the case law of the CJEU, starting with the Rush Portuguesa decision of $1990 .{ }^{93}$ In this case, the CJEU made a distinction between migrant workers, who enter the labour market of the host state, and posted workers, who generally do not. Posted workers are workers who, while normally employed in a certain Member State, are temporarily posted to another Member State to perform a service there. The employer of a posted worker makes use of the free movement of services. The worker does not need to avail himself of the free movement of workers, because he is not deemed to enter the labour market of the host state. ${ }^{94}$ This distinction is crucial in case the worker does not enjoy free movement himself, e.g. because he is covered by a transitional regime. But the distinction also had an impact on the labour law protection of the workers involved.

The underlying assumption in the case law on the free movement of services is that workers who ordinarily work in the country of establishment of their employer will be covered by the law of their (employer's) home state, even when they are temporarily posted to another state (the host state) to perform services there. However, this causes a differentiation of employment conditions applying to workers employed on the same site. The local workers would be protected according to local standards, whereas the posted workers would be protected according to the standards of the home state. This inequality in labour protection leads to a comparative advantage for firms established in low-cost countries, which in turn may negatively affect the employment conditions in the host state (social dumping). Accordingly, high-cost states might want to extend their employment protection rules to all labour performed within the territory. And in practice they did. Germany, for example, adopted a special statute to ensure that workers posted to Germany would enjoy a certain level of minimum wage protection. ${ }^{95}$ However, general appli-

91. This was already stipulated in the Arblade case: ECJ 23 November 1999, C-369/96, ECR 1999, I-8453.

92. Compare CJEU 17 October 2013, C-184/12 (Unamar), nyr, para. 51.

93. ECJ 27 March 1990, C-113/89, ECR 1990, I-1417 (Rush Portuguesa Lda v. Office National d'Immigration).

94. This may be different when the worker is send abroad by a temporary work agency: CJEU 10 February 2011, Joint Cases C-307/09, C-308/09 and C-309/09 ECR 2011, l-453 (Vicoplus).

95. The Arbeitnehmerentsendegesetz (BGBI. I 227) was adopted in 1996. In the Netherlands, the scope of the most relevant collective agreement - the one for the construction sector - was adapted to include workers posted to the Netherlands. Belgium and France already applied their laws to work within the territory. 
cation of host state law would put the foreign service provider at a disadvantage by obliging him to fulfil double standards (both those of the home state and those of the host state) as well as robbing him of the comparative advantage described above. This, according to the CJEU, constitutes an obstacle to the free provision of services, which can only be justified under specific conditions. $^{96}$

As the very diverging interpretation of Article 7 Rome Convention in the Member States led to legal uncertainty, secondary legislation seemed necessary. ${ }^{97}$ However, agreement was not reached easily. ${ }^{98}$ The posting of workers in the context of the free provision of services opposes the interests of host state providers and workers to the interests of the company performing the crossborder service (and sometimes even the interests of the posted workers). But it also opposes the interests of high-cost host states to those of low-cost sending states. ${ }^{99}$ This makes the topic highly controversial. ${ }^{100}$ The PWD adopted in 1996 (before the accession to the $\mathrm{EU}$ of the former Eastern European countries) tries to balance the interest involved.

\subsection{The PWD}

The PWD applies to cross-border posting of workers in the context of an intra-EU provision of services. ${ }^{101}$ The directive covers different types of posting which are described in Article 1 PWD and include service contracts, intra-company transfers and temporary agency work. Article 2 PWD defines a posted worker as a 'worker who, for a limited period, carries out his work in the territory of a Member State other than the State in which he normally works' - a phrase which mimics (but is not identical to) the connecting factor of Article 8(2) Rome I Regulation. The substantive protection of the PWD is contained in Article 3. This article imposes a duty on the host state to extend its mandatory labour protection in certain core areas of labour law to workers who are temporarily posted to their territory in

96. See inter alia ECJ 23 November 1999, C-369/96, ECR 1999, I-8453 (Arblade) and ECJ 15 March 2001, C-165/98, ECR 2001, I-2189 (Mazzoleni).

97. The directive also regulates the enforcement of rights and contains a special rule on jurisdiction.

98. On the history of the PWD see M.S. Houwerzijl, De Detacheringsrichtlijn. Over de achtergrond, inhoud en implementatie van richtlijn 96/71/EG (2005)

99. M. Fornasier and M. Torga, 'The Posting of Workers: Perspective of the Sending State', 6 Europäische Zeitschrift für Arbeitsrecht 356-65, at 358 (2013).

100. The controversial character may also be deduced from the large number of amendments (833) which were submitted for the draft report on the enforcement directive of the committee on employment of the EP (procedure file 2012/0061/COD). A similar lively discussion took place in the legislative procedure for the Services directive. In the final version, employment conditions were specifically excluded from the home country control rule embedded therein: Directive 2006/123/EC of the European Parliament and of the Council of 12 December 2006 on services in the internal market, OJ 2006, L 376/36-68, Article 3(1)(a), 3(2) and recital 14.

101. The directive only regulates intra-EU provision of services. However, Article 1(4) stipulates that 'Undertakings established in a non-member State must not be given more favourable treatment than undertakings established in a Member State.' the context of a cross-border provision of services. This obligation provides a certain measure of fair competition for all companies performing services within a given state by laying a minimum threshold in the level of protection offered to the workers. The other articles of the directive relate to exchange of information, enforcement, implementation and review.

Article 3 is the heart of the posting directive. As described, it ensures a minimum level of protection through the mechanism of equal treatment of posted and local workers. The directive does not compel states to introduce certain types of protection, e.g. a statutory minimum wage. However, when a Member State does offer its own work force a specific protection, this protection should also apply to posted workers. In other words, the PWD does not harmonise the substantive law, but does regulate the application thereof in international cases. Because of this character, Article 3 PWD is deemed to be a private international law provision which gives a specific interpretation of Article 9 Rome I: all mandatory rules in the areas of protection mentioned in Article 3 PWD (minimum wage, non-discrimination, safety and health, maximum working time) must be considered to apply as overriding mandatory protection to all workers posted to the territory. ${ }^{102}$

However, the CJEU interpreted the PWD as to also limit the application of host state labour law to the areas mentioned in the directive, unless the rule to be applied is considered to be part of public policy. ${ }^{103}$ In other words, the PWD constitutes both the minimum and the maximum rule on the application of host state law in the context of intra-EU provision of services.

\subsection{The Interaction between the PWD and the Rome I Regulation}

There is an uncertain factor though: the exact interaction between the PWD and the Rome I Regulation has yet to be clarified. ${ }^{104}$ Whereas the PWD, in the situations covered by it, clearly seems to limit the possibility of host states to apply their local laws and regulations as overriding mandatory provisions, it is less clear to what extent the PWD would also limit the application of host state law as the law applying by virtue of Article 8 Rome I. The first sentence of Article 3(7) PWD allows the Member States to offer better protection to posted workers than the minimum provided for by the directive. The CJEU has interpreted this provision to refer only to better protection offered by the law of the 'country of origin' - extension of protection by the host state

102. Beaumont and McEleavy, above n. 63, at 534; Vonken, above n. 87 , at 450.

103. The directive also has an influence on the way the minimum level of protection should be established - e.g. by law or generally applicable collective agreement. Moreover, two provisions allow for additional protection in case of employment through temporary work agencies.

104. Van Hoek and Houwerzijl, above n. 77, at 15-21. 
is not covered by it. ${ }^{105}$ Some authors infer a home country control rule from this case law, which would submit the posted worker to the laws of the country of establishment of his employer and disallow the application of more favourable provisions contained in the law applicable by virtue of Article 8 of Rome I. ${ }^{106}$ A different reading - and the one I adhere to - denies the existence of a home country control rule with regard to employment protection. ${ }^{107}$ In that view the 'country of origin' in the court's case law should be read to refer to the country in which the work is normally or habitually performed, rather than the country of establishment of the employer. ${ }^{108}$ The law applying to the employment contract under Article 8 of Rome I may be applied in full, even if this law happens to be the law of the host state.

The discussion on the potentially limiting effect of the PWD on the law applicable to the contract under Article 8 of Rome $I$ is spawned to a large extent by the fact that most Member States have not implemented the definitions of posting and posted worker in their national laws. They simply apply the rules on posting to all or almost all cross-border service provisions. ${ }^{109}$ As a result, also workers who do not normally perform their work in the state of establishment of their employer, but rather are hired for posting, are treated as 'posted workers' and exempted from the protection of host state law. ${ }^{110}$ To give but one example, in the Flamanville case Polish workers were employed by the Cypriot establishment of

105. See in particular CJEU C-346/06 ECR 2008, I-1989, (Rüffert) para. 34. The CJEU also allows the employer to voluntary improve the protection of the workers by entering into collective agreements in the host state: CJEU 18 December 2007, C-341/05, ECR 2007, I-11767 (Laval) paras. 80-81.

106. See e.g. F. van Overbeeke, 'Over de interactie tussen het IPR en de bepalingen inzake het vrij verkeer, toegespitst op internationale arbeidsovereenkomsten', Rechtskundig Weekblad 643-53, at 648 ff. (2013); Fornasier and Torga, above n. 99 at 364 . Those authors draw a parallel between this situation and that of the eDate decision of the CJEU 25 October 2011, C-509/09 and C-161/10. However, I would submit there are crucial differences between the eDate scenario and the situation discussed here. See in more detail (with references): A.A.H. van Hoek and M.S. Houwerzijl, "Posting" and "Posted Workers": The Need for Clear Definitions of Two Key Concepts of the Posting of Workers Directive', in C. Barnard, M. Gehring \& I. Solanke (eds.), Cambridge Yearbook of European Legal Studies (2012) 419-51.

107. Compare Van Hoek and Houwerzijl, above n. 106, at 441-43. Employment conditions are specifically excluded from coordinated field in the Services directive: Directive 2006/123/EC of the European Parliament and of the Council of 12 December 2006 on services in the internal market, OJ 2006, L 376/ 36-68, Articles 3(1)(a), 3(2) and recital 14.

108. It should be kept in mind, though, that in most cases in which host state law would apply by virtue of Article 8 Rome I, the worker would not qualify as posted worker under Article 2 PWD. Compare Van Hoek and Houwerzijl, above n. 106, at 424 and 448.

109. Van Hoek and Houwerzijl, above n. 4, at $74 \mathrm{ff}$.

110. Lisa Berntsen and Nathan Lillie, Organizing a Transnational HyperMobile Workforce in the Dutch Construction Sector, at $11<w w w 2$ gre. ac.uk/_data/assets/pdf_file/0010/665740/Lisa-Berntsen-and-Nathan-

Lillie.pdf>. For the difficulty of distinguishing genuine postings from other types of labour mobility, see also Jan Cremers, 'In Search of Cheap Labour in Europe: Working and Living Conditions of Posted Workers', 6 CLR Studies, EFBW (2011), executive summary <www.clrnews.org/CLR-Studies/Websummary.pdf>, Roberto Pedersini and Massimo Pallini, 'Posted Workers in the European Union', Eurofound (2011), $13<$ www.eurofound.europa.eu/eiro/studies/tn0908038s/tn0908038s_2. htm>. an Irish recruitment agency to work at a construction site in France. ${ }^{111}$ In this case, the employer was performing a cross-border provision of services. But the workers were not posted in the meaning of either the PWD or Article 8 Rome I; they may very well have been covered by the law of the host state as lex causae.

The over-application of the PWD may be halted when the directive on the enforcement of the PWD is implemented. ${ }^{112}$ The enforcement directive inter alia contains an operationalisation of the concepts of posting and posted worker, limiting the application of the PWD to situations of genuine posting. The clarification of the scope of the PWD led to a discussion on the legal position of workers employed in the context of cross-border service provisions who do not fulfil the requirements of a genuine posting. The parliamentary documents show a three-fold opinion on this matter. Some MEPs advocated that host state law should apply in full. This position supports the call for equal treatment between locally hired and posted workers. ${ }^{113}$ Others advocated that a comparison should be made between home state and host state law, giving precedence to the law offering better protection. ${ }^{114}$ Finally, the third opinion, which turned into law at the adoption of the directive, refers to the Rome I Regulation with regard to the issue of applicable law. ${ }^{115}$ The exact implications of this latter position for the interpretation of Articles 8 and 9 Rome I Regulation are yet unclear, though.

For one, the debate in parliament and Council seems to centre around the interaction between the PWD and Article 8 Rome I. None of the amendments presented in the debate in parliament specifically address the interaction between the PWD and Article 9 Rome I. When workers employed in a cross-border situation do not fulfil the definition of posting under the PWD, the host state is not obliged to offer the protection specified

111. <www.eurofound.europa.eu/eiro/2012/07/articles/fr1207031i.htm>; $<$ www.europarl.europa.eu/sides/getDoc.do?pubRef=-//EP//TEXT+OQ+O $-2011-000168+0+D O C+X M L+V 0 / / E N>$

112. Directive 2014/67/EU of the European Parliament and of the Council of 15 May 2014 on the enforcement of Directive 96/71/EC concerning the posting of workers in the framework of the provision of services and amending Regulation (EU) No. 1024/2012 on administrative cooperation through the Internal Market Information System ('the IMI Regulation') OJ 2014 L 159/11.

113. During the debate in Council it was suggested to apply host state law to any worker not fulfilling the definition of posted worker as specified in the Enforcement Directive. See debate in council 21/6/2012 and 6/12/2012, Procedure file 2012/0061/COD. Similar solutions were proposed by members of the European Parliament. See e.g. amendments 378, 388, 393, 201 and 402 accompanying the Draft report.

114. Compare Draft report, amendments nos. 384, 388 and 399. The Report of the EP, 4 July 2013, PE 498.030v02-00 A70249/2013 (amendments 5 and 45) primarily refers to the law applying on the basis of the Rome I Regulation, but seems to link interpretation thereof to an assessment which law is most favourable to the posted workers.

115. See Report, amendments 5 and 45. The Commission proposal, $\operatorname{COM}(2012) 131$ final, specifies in recital 6 that the PWD 'should not prejudice the application of the law which, under Article 8 Rome I Regulation, applies to individual employment contracts'. Interim solutions may call upon the Member State to jointly establish the applicable law to the contract, or introduce an assumption that in cases of 'non-genuine posting', the host state is the state in which the work is habitually performed under Rome I: see Draft report, amendments 90 and 119. 
therein. However, the limitation to core issues and public police does not apply either. Suppose a worker can no longer be deemed to be a posted worker, because she is not posted for a short period and is not expected to return to the country of origin upon termination of the cross-border service (the Schlecker scenario). What protection does this worker enjoy when, based on the wide interpretation of the exception clause in Article 8 Rome I, the law of the country of origin is applicable to the employment contract as such? Similarly, the question could be raised on the protection of workers in the Flamanville scenario described above. The current interpretation of Article 8 Rome I by the CJEU makes it difficult to predict which law would apply to their contracts. This puts pressure on the use of Article 9 Rome I as a regulatory mechanism. In my opinion host state law should at least provide the Flamanville workers with the minimum protection offered by the PWD, in order to avoid an unwanted lacuna in the protection of this group of workers. ${ }^{116}$ However, as the maximum imposed by the PWD does not apply either, the host state is free to apply mandatory laws going beyond the core protection of the PWD, provided the requirements of both Article 9 Rome I and - where necessary - the case law on the treaty provisions regarding free movement are met. ${ }^{117}$

\section{Some Conclusions}

The CJEU has a very factual and case-specific approach to the determination of the applicable law in employment disputes. The emphasis placed on the factual performance of the contract is meant to protect the worker by ensuring the application of a law which has a real connection to the employment contract and/or the social and economic environment in which the employee operates. It counteracts the possibilities for 'labour law shopping' which the free movement provisions of EU law offer the employer. However, the factual character of the assessment may have serious procedural drawbacks for the employee as well as reducing legal certainty. Moreover, the strictly individual character of the choice-of-law process may hamper administrative and collective enforcement of the rights of the workers involved.

In the Schlecker case the CJEU prioritised the individual assessment of the applicable law over more collective concerns. By opening up the possibility to apply the law of the country of the common origin of the parties even in cases in which the contract has been performed for a continuous and prolonged period in a single other country, the court seems to take position in the discussion whether and to what extent the protection of 'posted' workers should be equal to the protection of workers habitually working in the country of posting. By leaving so much room for application of the law of the country

116. Compare Hof Den Bosch 28 May 2013, ECLI:NL:GHSHE:2013:CA1457, JAR 2013/159, RAR 2013/160 (Mooy).

117. On the latter, see Pedersini and Pallini, above n. 110 at 19-20. of (common) origin, ${ }^{118}$ the judgment stands in clear opposition to the plea of the national and European labour unions for equal treatment of all employees who perform their work in a specific state. ${ }^{119}$

Both the factual and the individualised character of the choice of law process diminish the aptitude of Article 8 Rome I as an instrument for the regulation of crossborder labour mobility. This is remedied in part by Article 9 - an article which specifically aims to protect public interests and hence has a more regulatory goal.

Article 9 Rome I offers a point of entry for the overriding mandatory provisions of the state in which the work is actually performed, in case foreign law applies to the contract as such. However, the application of host state law in the area of cross-border provision of services within the EU is strictly regulated by the PWD.

The recently adopted Enforcement Directive will reduce the role of the PWD to a situation of genuine posting, in which the applicable law to the contract will most likely be the law of the country of origin of the service provider/employer. In those cases, private international law and internal market rules coincide. Outside this ideal type of posting, however, the interaction between the rules on the internal market and private international law are still cause for confusion and debate. As both areas of law are based on different logics - the one taking the service provider as its starting point and the other the individual contract of employment - this debate is unlikely to end with the Enforcement Directive.

118. The CJEU does not refer to the country of origin. However, the reference to the tax and social security position of the worker in practice does act as an indirect country of origin / home country control rule. See also above.

119. On the opinion of the European Trade Union Confederation, see $<$ www.etuc.org/r/909>; for the position of the Dutch trade union confederations, see <www.cnv.nl/blog/blog-post/2012/03/20/detacherings richtlijn-niet-scherp-genoeg/>. 